\title{
AKRUAL
}

Jurnal Akuntansi

http://fe.unesa.ac.id/ojs/index.php/akrl

\section{KESEMPATAN INVESTASI DAN DETERMINAN KEBIJAKAN PENDANAAN PERUSAAHAAN PUBLIK INDONESIA}

\author{
Rowland Bismark Fernando Pasaribu \\ Universitas Gunadarma \\ Email: rowland_pasaribu@staff.gunadarma.ac.id \\ Dionysia Kowanda \\ Universitas Gunadarma \\ Email: dion@staff.gunadarma.ac.id \\ Artikel diterima: 5 Juli 2013 \\ Terakhir direvisi: 10 Agustus 2013
}

\begin{abstract}
This research aimed to test whether there are differences among companies which have the growth potential and barren of in the case of policy of financing and also to test significance influence of unsystematic risk, size, profitability, and liquidity to non-financial companies financing structure enlisted in Indonesian Stock exchange Period 2008-2011. The result of this research indicate that except of debt equity ratio, size, and unsystematic risk, generally, there is differences of all proxy (leverage, profitability, and liquidity) between company which have the potency to grow and barren of. Hitting the influence significantly, in simultaneously all proxy used have a significant influence to structure of company financing in both classification refer to IOS.
\end{abstract}

Keywords: Investment Opportunity Set, Leverage, Size, Unsystematic Risk, Profitability, Liquidity

\section{PENDAHULUAN}

Tidak ada yang mengetahui secara pasti kapan suatu perusahaan dikatakan berpotensi tumbuh dan tidak tumbuh. Berbagai penelitian empiris keuangan mencoba untuk memberikan ukuran-ukuran tertentu berikut justifikasi normatifnya. Ada yang mencoba mengaitkan dari perspektif aspek-aspek strategi stakeholder perusahaan, namun tidak sedikit yang mencoba menganalisis dengan pendekatan informasi keuangan historis. Pendekatan strategik biasanya menggunakan beberapa tahapan pertimbangan yang cukup kompleks dalam memastikan probabilitas pertumbuhan suatu perusahaan, beberapa diantaranya: fleksibilitas perusahaan dalam menghadapi fluktuasi indikator makro dan moneter, regulasi pemerintah, dan adaptasi perkembangan teknologi dalam operasionalisasinya.

Sementara pendekatan kinerja keuangan historikal, lebih sederhana dalam memberikan justifikasi ukuran pertumbuhan perusahaan. Salah satu pendekatan kinerja keuangan historikal yang populer adalah analisis fundamental. Pendekatan ini mengasumsikan bahwa setiap saham memiliki nilai intrinsik yang dapat 
ditentukan berdasarkan fundamental perusahaan seperti laba, dividen, struktur modal, dan potensi pertumbuhan perusahaan. Nilai intrinsik disebut juga nilai fundamental yaitu nilai yang mencerminkan nilai perusahaan yang sebenarnya. Analisis secara detail dengan pendekatan ini lebih memfokuskan pada laporan keuangan untuk pendeteksian perbedaan antara harga pasar sekuritas dengan nilai intrinksiknya. Nilai intrinsik saham juga dapat menunjukkan karakteristik perusahaan sebagai dasar untuk mengetahui apakah suatu saham dinilai lebih rendah (undervalue) atau lebih tinggi (overvalue). Potensi pertumbuhan dapat ditunjukkan dengan perbandingan antara nilai pasar saham dengan nilai bukunya.

Dari perbedaan substansial dua pendekatan tersebut, maka tidaklah heran bahwa proksi kesempatan investasi memiliki beragam definisi operasional dalam penelitian keuangan (baik dalam konteks studi empiris dan pemodelan). Namun demikian, garis merah di antara keduanya bertemu pada pemahaman bahwa memang opsi investasi masa depan perusahaan tidak semata-mata hanya ditunjukkan dengan adanya proyek-proyek yang didukung oleh kegiatan riset dan pengembangan saja, tetapi juga dengan kemampuan perusahaan yang lebih dalam mengeksploitasi kesempatan mengambil keuntungan dibandingkan dengan perusahaan yang setara dalam suatu kelompok industrinya. Kemampuan perusahaan yang lebih tinggi ini bersifat tidak dapat diobservasi, oleh karena itu, jika peneliti ingin mengetahui maka harus mencari dan menghitung sendiri. Berdasarkan pengertian tersebut para peneliti keuangan yang menggunakan pendekatan informasi historikal telah mengembangkannya menjadi proksi kesempatan investasi yang dijadikan sebagai dasar untuk menentukan apakah suatu perusahaan masuk dalam klasifikasi yang tumbuh atau tidak tumbuh.

Adam dan Goyal (2008) menyatakan bahwa dalam membuat keputusan investasi, setiap perusahaan dapat berinvestasi dalam bentuk modal fisik dan sumber daya manusia secara khas. Investasi spesifik perusahaan tersebut mengakibatkan adanya variasi dalam seperangkat kesempatan investasi antar perusahaan yang terdiri atas variasi dalam kesempatan investasi yang prospektif serta ekspektasi distribusi hasil dari kesempatan investasi tersebut. Perbedaan keputusan investasi yang diambil oleh perusahaan dalam rangka menghadapi perusahaan pesaing yang hendak memasuki pasar serta variasi pilihan-pilihan strategi perusahaan dalam rangka memperoleh keunggulan kompetitif mengakibatkan pendekatan pengukuran IOS sangat bervariasi secara crosssectional antar perusahaan dan industri. Demikian juga stakeholder yang berkepentingan dengan ukuran IOS suatu perusahaan ini, tentu memiliki kepentingan yang tak sama. Hubungan antara IOS dengan kinerja manajemen misalnya, ditunjukkan oleh adanya pertumbuhan nilai perusahaan yang dikelola oleh manajemen dimana realisasi pertumbuhan perusahaan ditunjukkan dalam pertumbuhan nilai aset, penjualan, laba dan nilai buku perusahaan.

Seiring perkembangan waktu, penelitian mengenai kesempatan investasi di Indonesia sangatlah dinamis, positioning proksi IOS ini bisa menjadi prediktor, diskriminator, atau variabel dependen. Dengan kata lain, proksi kesempatan investasi ini memang dianggap berpengaruh pada manajer, pemilik, investor, ataupun kreditor terhadap perusahaan itu sendiri. Namun sebagian besar kajian mengenai IOS ini sering dikaitkan dengan kebijakan pendanaan dan dividen. Asosiasi antara kesempatan investasi dengan kebijakan pendanaan, dividen, 
kompensasi perusahaan telah ditemukan buktinya oleh studi yang dilakukan oleh Yanto (2012), Nugraha dan Sampurno (2012), Martati (2010), Aini (2010), Wardani dan Siregar (2009), Kumar, (2007), Wijayanto (2011), Zahrotus (2009), Prapaska (2012), Yulianti (2007), Wisudha (2007), Zahrotus dan Zuhrotun (2009), Andriyani (2008), Batubara (2012), Dachi (2010), Suharli (2006), Susilo (2011), Mutiah (2012), Putri (2011). Proksi kesempatan investasi juga dianggap memiliki pengaruh terhadap saham emiten, baik itu dalam hal volume trading, tingkat pengembalian saham atau reaksi pasar (tingkat pengembalian tak normal) pada penelitian-penelitian tedahulu yang dilakukan Barus (2008), Bintary (2008), Gultom (2011), Gusrifa (2007), Kurniasi dan Andriana (2011), Mindania (2013), Setiarini (2006), Putri (2011). Secara umum, asumsi penelitian mereka mengatakan bahwa seharusnya pasar memberikan respon positif terhadap emiten yang berpotensi tumbuh, dan hal sebaliknya. Sedangkan asosiasi antara IOS dan kebijakan pilihan prosedur akuntansi telah dibuktikan oleh Tjandra (2005). Demikian juga, asosiasi antara IOS dengan kebijakan keterbukaan informasi dan tata kelola yang baik telah dilakukan oleh Adriani (2011), Puteri dan Rohman (2012), Putra (2013).

Karakteristik pertumbuhan perusahaan ini juga dapat memberikan manfaat bagi investor, para analis sekuritas, dan stakeholder lainnya dimasa yang akan datang dalam menentukan keputusan investasinya. Bagi investor dan analis saham manfaatnya adalah sebagai salah satu cara untuk menentukan saham-saham yang akan dijadikan pembentuk portofolio saham karena klasifikasi potensi pertumbuhan perusahaan dapat mengindikasikan suatu risiko yang melekat pada saham perusahaan. Hubungan antara potensi pertumbuhan perusahaan dengan risiko suatu saham telah ditemukan buktinya oleh Purnomo (2005) dan Puspitasari, dan Gumanti (2005), yang dalam studi mereka berpendapat bahwa perusahaan yang tidak berpotensi tumbuh mempunyai risiko tidak sistematis lebih tinggi dibandingkan dengan perusahaan yang berpotensi tumbuh.

Relevansi ukuran perusahaan juga dianggap berpengaruh terhadap kesempatan pertumbuhan perusahaan (Mutiah, 2012; Nugraha dan Sampurno, 2012; Pasaribu, 2012), Mulyono (2009). Adagium justifikasinya adalah perusahaan yang besar dan mapan (stabil) akan lebih mudah untuk ke pasar modal. Kemudahan untuk ke pasar modal maka berarti fleksibilitas bagi perusahaan besar lebih tinggi serta kemampuan untuk mendapatkan dana dalam jangka pendek juga lebih besar daripada perusahaan kecil. Dari uraian singkat diatas penelitian terdahulu yang terdekat dengan penelitian ini adalah studi yang dilakukan Yanto (2012), Yulianti (2007), Akibar (2011), dan Aini (2010), yakni menggunakan teori IOS dalam kaitannya dengan kebijakan pendanaan pada emiten di pasar modal yang sedang berkembang khususnya pada Bursa Efek Indonesia serta signifikansi parsial dan simultan pengaruh beta saham, size, profitabilitas, dan likuiditas terhadap struktur pendanaan emiten yang berpotensi tumbuh dan tidak tumbuh periode 2008-2011. 


\section{Perumusan Masalah}

Berdasarkan latar belakang yang telah dikemukakan maka perumusan masalah dalam penelitian ini adalah:

1. Apakah terdapat perbedaan antara emiten yang berpotensi tumbuh dan tidak tumbuh dalam hal kebijakan pendanaan?

2. Apakah terdapat pengaruh yang signifikan antara beta saham, size, profitabilitas, dan likuiditas terhadap struktur pendanaan emiten yang berpotensi tumbuh dan tidak tidak tumbuh?

\section{Tujuan Penelitian}

Tujuan yang ingin dicapai dalam penelitian ini adalah:

1. Menghitung perbedaan antara emiten yang berpotensi tumbuh dan tidak tumbuh dalam hal kebijakan pendanaan.

2. Menghitung pengaruh beta saham, size, profitabilitas, dan likuiditas terhadap struktur pendanaan emiten yang berpotensi tumbuh dan tidak tumbuh.

\section{KERANGKA TEORITIS DAN PENGEMBANGAN HIPOTESIS Kebijakan Pendanaan}

Kebijakan pendanaan suatu perusahaan ditentukan oleh tingkat kebutuhan investasi. Manajemen akan mencari dana untuk mendanai investasi tersebut. Kebijakan pendanaan harus dilakukan sesuai dengan kebutuhan perusahaan, apakah harus mengajukan pinjaman atau menerbitkan saham baru. Hal ini karena kebijakan pendanaan mempengaruhi nilai perusahaan. Menurut Pecking Order Theory, perusahaan akan menggunakan pendanaan internal jika tersedia (Brigham, dan Houston, 2006). Namun, jika dana internal tidak mencukupi, maka manajemen akan mencari sumber dana eksternal. Pada saat pendanaan eksternal dibutuhkan, perusahaan terlebih dahulu akan menerbitkan sekuritas yang paling aman yaitu perusahaan akan mulai dari hutang kemudian sekuritas campuran seperti obligasi konvertibel, kemudian ekuitas sebagai langkah terakhir.

Terdapat beberapa faktor yang memiliki pengaruh terhadap kebijakan hutang, antara lain :

1) NDT (Non-Debt Tax Shield, manfaat dari penggunaan hutang adalah bunga hutang yang dapat digunakan untuk mengurangi pajak perusahaan. Namun untuk mengurangi pajak, perusahaan dapat menggunakan cara lain seperti depresiasi dan dana pensiun. Dengan demikian, perusahaan dengan NDT tinggi tidak perlu menggunakan hutang yang tinggi.

2) Struktur Aset, besarnya aset tetap suatu perusahaan dapat menentukan besarnya penggunaan hutang. Perusahaan yang memiliki aset tetap dalam jumlah besar dapat menggunakan hutang dalam jumlah besar karena aset tersebut dapat digunakan sebagai jaminan pinjaman.

3) Profitabilitas, perusahaan dengan tingkat pengembalian yang tinggi atas investasinya akan menggunakan hutang yang relatif kecil. Laba ditahan yang tinggi sudah memadai membiayai sebagian besar kebutuhan pendanaan.

4) Risiko Bisnis, perusahaan yang memiliki risiko bisnis yang tinggi akan menggunakan hutang yang lebih kecil untuk menghindari risiko kebangkrutan. 
5) Ukuran Perusahaan, perusahaan yang besar cenderung terdiversifikasi sehingga menurunkan risiko kebangkrutan. Di samping itu, perusahaan yang besar lebih mudah dalam mendapatkan pendanaan eksternal.

6) Kondisi Internal Perusahaan, kondisi internal perusahaan menentukan kebijakan penggunaan hutang dalam suatu perusahaan.

Kebijakan hutang merupakan kebijakan yang diambil oleh pihak manajemen dalam rangka memperoleh sumber pembiayaan bagi perusahaan sehingga dapat digunakan untuk membiayai aktivitas operasional perusahaan. Kebijakan hutang juga dipandang sebagai mekanisme internal kontrol yang dapat mengurangi konflik keagenan antara manajemen dan pemegang saham. Penambahan hutang dalam struktur modal dapat mengurangi penggunaan saham sehingga mengurangi biaya keagenan ekuitas. Selain itu, perusahaan memiliki kewajiban untuk mengembalikan pinjaman dan membayar beban bunga secara periodik. Kondisi ini menyebabkan manajemen bekerja lebih keras untuk meningkatkan laba sehingga dapat memenuhi kewajiban dari penggunaan hutang. Selain mengurangi konflik keagenan, hutang dapat menguntungkan bagi perusahaan, terutama dalam hal pengurangan jumlah pajak yang harus dibayarkan kepada pemerintah, karena penurunan jumlah pajak yang harus dibayarkan dapat meningkatkan jumlah kas yang tersedia untuk didistribusikan kepada pemegang saham dan kreditor.

Manajemen harus mempertimbangkan nilai manfaat pengajuan hutang dimana biaya hutang berupa biaya bunga harus lebih rendah daripada manfaat yang akan diperoleh perusahaan. Selain itu, manajemen juga perlu memperhitungkan distress cost yang akan ditimbulkan dari hutang yang semakin tinggi. Distress cost ini berkaitan dengan biaya-biaya yang akan dikeluarkan apabila terjadi kebangkrutan (bankruptcy costs), biaya tidak langsung (indirect cost) berupa biaya yang timbul akibat kehilangan penjualan atau pendapatan, serta konflik kepentingan yang akan terjadi dimana pihak kreditor dan pemegang saham akan mengkhawatirkan pengembalian atas dana mereka.

Kebijakan pendanaan suatu perusahaan dapat dilihat dari rasio solvabilitas, yaitu rasio yang digunakan untuk mengukur kemampuan perusahaan untuk membayar seluruh kewajibannya, baik jangka pendek maupun jangka panjang. Jenis rasio solvabilitas yang digunakan dalam penelitian ini adalah debt to equity ratio (DER) dimana rasio ini membandingkan antara total hutang, termasuk hutang lancar dengan total ekuitas. Rasio ini berguna untuk mengetahui jumlah dana yang disediakan kreditor dengan pemilik perusahaan yang berkaitan dengan kebijakan pendanaan perusahaan.

Bagi kreditor, semakin tinggi debt to equity ratio, akan semakin tidak menguntungkan karena risiko yang akan ditanggung atas kegagalan yang mungkin terjadi pada perusahaan akan semakin tinggi. Debt to equity ratio juga memberikan petunjuk umum tentang kelayakan dan risiko keuangan perusahaan. 


\section{Risiko Sistematik}

Risiko adalah kemungkinan untuk mendapatkan keuntungan yang lebih rendah dari yang diharapkan atau tidak akan menerima apapun dari investasi. Setiap berinvestasi pasti akan menanggung risiko. Jogiyanto (2009) mendefinisikan risiko sebagai variabilitas pendapatan yang diharapkan. Risiko suatu investasi diukur dari besarnya varians atau standar deviasi dari pengembalian yang diharapkan atau kemungkinan tingkat pengembalian yang diperoleh menyimpang dari yang diharapkan. Semakin besar penyebaran maka investasi tersebut akan semakin berisiko. Risiko yang digunakan dalam penelitian ini adalah risiko sistematis, yakni risiko yang disebabkan oleh faktor-faktor yang secara bersamaan mempengaruhi harga saham di pasar modal. Risiko ini ada karena adanya perubahan ekonomi secara makro atau politik seperti kebijakan fiscal pemerintah, pergerakan tingkat suku bunga, nilai tukar mata uang, dan inflasi. Semua ini dapat menyebabkan reaksi pasar modal yang dapat dilihat dari indeks pasar. Risiko sistematis akan selalu ada dan tidak dapat dihilangkan dengan diversifikasi. Risiko ini tidak dapat dikontrol karena dipengaruhi oleh risiko pasar.

\section{Ukuran Perusahaan}

Ukuran perusahaan merupakan salah satu faktor yang perlu dipertimbangkan dalam menentukan tingkat kebijakan hutang yang akan dilakukan perusahaan. Ukuran perusahaan menggambarkan besar kecilnya suatu perusahaan yang dapat dinyatakan dengan total aset atau total penjualan bersih. Menurut Husnan (2005), semakin besar total aset maupun penjualan maka semakin besar pula ukuran suatu perusahaan. Semakin besar aset maka semakin besar modal yang ditanam, sementara semakin banyak penjualan maka semakin banyak juga perputaran uang dalam perusahaan. Dengan demikian, ukuran perusahaan merupakan ukuran atau besarnya asset yang dimiliki oleh perusahaan.

Ukuran perusahaan secara langsung mencerminkan tinggi rendahnya aktivitas operasi suatu perusahaan. Umumnya semakin besar suatu perusahaan maka akan semakin besar pula aktivitasnya. Dengan demikian, ukuran perusahaan juga dapat dikaitkan dengan besarnya kekayaan yang dimiliki oleh perusahaan. Perusahaan yang besar dan mapan (stabil) akan lebih mudah untuk ke pasar modal. Kemudahan untuk ke pasar modal maka berarti fleksibilitas bagi perusahaan besar lebih tinggi serta kemampuan untuk mendapatkan dana dalam jangka pendek juga lebih besar daripada perusahaan kecil.

Ukuran perusahaan juga memiliki pengaruh penting terhadap integrasi antar bagian dalam perusahaan, Hal ini disebabkan karena ukuran perusahaan yang besar memiliki sumber daya pendukung yang lebih besar dibanding perusahaan yang lebih kecil. Pada suatu perusahaan yang kecil maka kompleksitas yang terdapat dalam organisasi juga kecil. Perusahaan kecil sangat rentan terhadap perubahan kondisi ekonomi dan cenderung kurang menguntungkan, sedangkan perusahaan besar dapat mengakses pasar modal dan dengan kemudahan tersebut maka dapat disimpulkan bahwa perusahaan memiliki fleksibilitas dan kemampuan untuk mendapatkan dana atau permodalan. Faktanya, perusahaan besar cenderung lebih mudah untuk memperoleh pinjaman dari pihak ketiga, karena kemampuannya mengakses pihak lain atau jaminan yang dimiliki berupa asset 
bernilai lebih besar dibanding perusahaan kecil. Selain itu, perusahaan besar akan cenderung menggunakan dana seiring pertumbuhannya. Perusahaan besar akan lebih aman dalam memperoleh hutang karena perusahaan mampu dalam pemenuhan kewajibannya dengan adanya diversifikasi yang lebih luas dan memiliki arus kas yang stabil.

\section{Likuiditas}

Likuiditas adalah kemampuan perusahaan dalam memenuhi kewajiban keuangan pada saat di tagih atau hutang jangka pendeknya. Perusahaan yang mempunyai likuiditas yang tinggi akan cenderung tidak menggunakan pembiayaan dari hutang. Hal ini disebabkan perusahaan dengan likuiditas tinggi mempunyai dana internal yang besar, sehingga perusahaan tersebut akan lebih dahulu untuk membiayai investasinya sebelum menggunakan pembiayaan eksternal melalui hutang. Kebutuhan dana untuk aset lancar pada prinsipnya dibiayai dengan kredit jangka pendek. Kemampuan membayar atas kewajiban jangka pendek sangat tergantung dari alat pembayaran likuid yang dimiliki perusahaan, besar alat pembayaran likuid yang dimiliki perusahaan disebut sebagai daya bayar atau kekuatan bayar suatu perusahaan yang akan menjadikan perusahaan mempunyai kemampuan membayar kewajiban jangka pendeknya.

\section{Profitabilitas}

Profitabilitas adalah kemampuan suatu perusahaan dalam memperoleh keuntungan, yang diindikasikan melalui besarnya laba yang diperoleh perusahaan tersebut. Semakin tinggi profitabilitas perusahaan semakin tinggi efisiensi perusahaan tersebut dalam memanfaatkan fasilitas perusahaan. Setiap perusahaan selalu berupaya agar memperoleh tingkat profitabilitas yang tinggi. Dalam konteks ini perusahaan yang menguntungkan tentunya tidak memerlukan banyak pembiayaan dengan hutang. Melalui adanya tingkat pengembalian yang tinggi memungkinkan perusahaan membiayai sebagian besar kebutuhan pendanaan mereka dengan dana yang dihasilkan secara internal. Para investor menanamkan saham pada perusahaan adalah untuk mendapatkan yield dan capital gain semakin tinggi memperoleh laba maka semakin besar return yang diharapkan investor. Margin laba bersih (net profit margin) merupakan keuntungan penjualan setelah dikurangi seluruh biaya dan pajak penghasilan. Rasio ini menunjukkan perbandingan antara laba bersih setelah pajak dengan penjualan.

\section{Set Kesempatan Investasi (IOS)}

Hubungan antara kesempatan tumbuh dimasa mendatang dan kebijakan pendanaan adalah isu sentral dalam manajemen keuangan korporat. Secara umum, banyak hasil penelitian yang mengemukakan bahwa market-to-book ratio sebagai ukuran kesempatan pertumbuhan memiliki arah hubungan yang negatif terhadap rasio leverag $e$ (Sibilkov, 2007). Sebagai contoh, mengikuti teori agensi, banyak para ekonom yang berpendapat bahwa hubungan negatif tersebut mengkonfirmasi bahwa semakin tinggi pertumbuhannya, maka semakin rendah rasio leverage perusahaan tersebut. Sebaliknya beberapa ekonom justru berpendapat bahwa hubungan tersebut dikarenakan market timing yang aktif (Baker dan Wurgler, 2002) dan target rasio leverage yang dibutuhkan (Welch, 2004). 
Munculnya istilah IOS dikemukakan oleh Myers (dalam Iturriaga, dan Crisostomo, 2010) yang menguraikan pengertian perusahaan, yaitu sebagai satu kombinasi antara aset riil dan opsi investasi masa depan. Selanjutnya proksi IOS ini dijadikan sebagai dasar untuk menentukan klasifikasi potensi pertumbuhan perusahaan dimasa depan apakah suatu perusahaan masuk dalam klasifikasi yang berpotensi tumbuh atau tidak berpotensi tumbuh. Proksi-proksi IOS yang telah digunakan oleh para peneliti secara umum dapat diklasifikasikan menjadi tiga kelompok berdasarkan pada faktor-faktor yang digunakan dalam mengukur proksi-proksi tersebut. Kelompok klasifikasi proksi IOS (Kallapur dan Trombley, dalam Akibar, 2011) tersebut adalah:

a. Proksi berdasarkan harga. Proksi berdasarkan harga ini percaya pada gagasan bahwa jika prospek yang tumbuh dari suatu perusahaan sebagian dinyatakan dalam harga pasar, maka perusahaan yang berpotensi tumbuh akan mempunyai nilai pasar relatif yang lebih tinggi dibandingkan dengan aset riilnya.

b. Proksi berdasarkan investasi. Proksi berdasarkan investasi ini percaya pada gagasan bahwa satu level kegiatan investasi yang tinggi berkaitan secara positif pada nilai IOS suatu perusahaan. Kegiatan investasi ini diharapkan dapat memberikan peluang investasi berikutnya yang semakin besar pada perusahaan yang bersangkutan.

c. Proksi berdasarkan varian. Proksi berdasarkan varian ini percaya pada gagasan bahwa suatu opsi akan menjadi lebih bernilai jika menggunakan variabilitas ukuran untuk memperkirakan besarnya opsi yang tumbuh, seperti variabilitas tingkat pengembalian yang mendasari peningkatan aset.

Penelitian ini menggunakan beberapa proksi sebagai dasar untuk mengukur nilai IOS, yaitu:

a. Rasio nilai buku aset tetap pada nilai buku perusahaan [PPE/BVA]. PPE/BVA $=[$ nilai buku aset tetap $] /[$ nilai buku perusahaan $]$

b. Rasio market to book value of equity [MVE/BVE]. MVE/BVE = [jumlah saham beredar $\mathrm{x}$ harga jual saham]/[total ekuitas]

c. Rasio earning to price $[\mathrm{E} / \mathrm{P}] . \mathrm{E} / \mathrm{P}=$ [laba bersih per saham (EPS)]: [harga jual saham]

d. Rasio market value of the firm to book value of assets $[\mathrm{A} / \mathrm{V}] . \mathrm{A} / \mathrm{V}=[$ total aset - total ekuitas + (saham beredar $\mathrm{x}$ harga jual saham)]/[total aset]

e. Rasio tambahan modal saham pada nilai buku aset [CAP/A]. CAP/A = [tambahan modal saham dalam tahun]/[nilai buku aset]

Penggunaan rasio PPE/BVA didasarkan bahwa aset tetap dapat menunjukkan indikator adanya investasi. Semakin besar rasio ini maka perusahaan akan mempunyai potensi untuk tumbuh yang juga semakin besar. Penggunaan nilai pasar perusahaan dan nilai pasar ekuitas yang diperbandingkan dengan nilai bukunya untuk menunjukkan proksi perusahaan yang mempunyai potensi untuk tumbuh dan berinvestasi dimasa depan. Perusahaan yang berpotensi tumbuh akan memiliki skor nilai pasar terhadap nilai bukunya lebih tinggi dibandingkan dengan perusahaan yang tidak berpotensi tumbuh. Hasil penelitian Adam dan Goyal (2008) menunjukkan bahwa rasio book-to-market of assets dan equity merupakan salah satu proksi potensi pertumbuhan yang valid, dan rasio ini mempunyai korelasi paling tinggi dengan pertumbuhan perusahaan pada masa 
yang akan datang. Lebih lanjut Abor dan Bokpin (2010) menyatakan bahwa penggunaan rasio E/P dalam proksi IOS karena rasio ini dapat menunjukkan indikator adanya aliran laba dimasa depan. Penggunaan proksi tambahan modal saham bagi perusahaan dapat berfungsi sebagai indikator adanya aliran dana untuk memperoleh kesempatan berinvestasi sehingga memungkinkan perusahaan untuk tumbuh dimasa depan.

\section{Penelitian Terdahulu}

Dari beragam positioning proksi IOS pada penelitian terdahulu, berikut adalah beberapa yang terdekat dengan penelitian ini: Bagaimana sesungguhnya pola hubungan kesempatan investasi dan kebijakan pendanaan, menjadi fokus pada studi yang dilakukan Martati (2010) dalam menjelaskan asosiasi kebijakan pendanaan dan seperangkat kesempatan investasi terhadap emiten manufaktur di Bursa Efek Indonesia. Hasil penelitiannya menunjukkan bahwa; a) set kesempatan investasi berbasis saham, dan investasi memberikan kontibusi terhadap set kesempatan investasi; b).Terdapat hubungan positif antara kebijakan pendanaan dengan IOS; c). Variabel BDER berpengaruh positif dan signifikan terhadap IOS sedangkan variabel MBDER tidak berpengaruh signifikan terhadap IOS.

Selanjutnya penelitian yang dilakukan Yanto (2012) bertujuan untuk menguji perbedaan kebijakan pendanaan dan dividen antara perusahaan tumbuh dan tidak tumbuh pada Bursa Efek Indonesia dengan pendekatan asosiasi proksi investment opportunity set. Studi pada perusahaan manufaktur yang terdaftar di Bursa Efek Indonesia periode 2006- 2009. Penelitiannya menggunakan enam proksi sebagai prediktor pertumbuhan perusahaan, yakni : ratio book value of groups property, plant, and equipment to the book value of the assets (PPE/BVA), ratio price to earning (PER), ratio market to book value of equity (MKTBKEQ), ratio market to book value of asset (MKTBKASS), capital expenditures to market value of asset (CAPMVA), dan capital expenditures to book value of asset (CAPBVA). Proksi ini dianalisis dengan common factor analysis. Empat puluh persen dengan IOS tertinggi masuk kategori tumbuh, empat puluh persen dengan IOS terendah masuk kategori tidak tumbuh, dan dua puluh persen dengan IOS di tengah dihilangkan. Hasil penelitiannya menunjukkan bahwa kebijakan pendanaan memiliki perbedaan yang signifikan pada perusahaan tumbuh dan tidak tumbuh dimana Debt to Equity Ratio (DER) perusahaan tumbuh lebih besar sedangkan Debt to Market Equity (MDE) perusahaan tumbuh lebih kecil. Sedangkan dari segi kebijakan dividen memiliki perbedaan yang signifikan pada perusahaan tumbuh dan tidak tumbuh dimana Dividend Payout Ratio (DPR) tidak berbeda namun Dividend Yields (DY) perusahaan tumbuh lebih kecil dibandingkan dengan perusahaan tidak tumbuh.

Di sisi lain, penelitian Aini (2010) bertujuan memberi bukti tambahan korelasi antara kesempatan investasi dan realisasi pertumbuhan perusahaan dan investigasi asosiasi antara kesempatan investasi dan pendanaan serta kebijakan dividen. Dengan menggunakan indikator MVA/BVA, MVE/BVE, PER, CAP/BVA, CAP/MVA sebagai proksi kesempatan investasi. Analisis faktor digunakan untuk mengklasifikasi perusahaan yang tumbuh dan tidak bertumbuh. Kalkulasi empiris menghasilkan temuan bahwa: 1) proksi CPA/MVA berkorelasi positif dengan realisasi pertumbuhan asset; 2) perusahaan yang tumbuh memiliki 
hutang yang rendah dan dividen yang tinggi dibanding dengan perusahaan yang tidak bertumbuh.

Pada penelitian Akibar (2011) variabel-variabel terukur dari proksi IOS individual di gabung menjadi satu variabel laten menggunakan structural equation models dengan pendekatan confirmatory factor analysis, yaitu membangun model dengan mendasarkan pada teori yang mendasari variabel-variabel terukur itu dalam variabel latennya. Gabungan proksi IOS ini akan dikorelasikan dengan realisasi pertumbuhan untuk melihat kemampuan dan konsistensi proksi IOS dalam memprediksi pertumbuhan perusahaan. Penelitiannya bertujuan untuk, a) menganalisis model gabungan proksi IOS dengan klasifikasi IOS memiliki kesesuaian dengan data sesungguhnya; b) menganalisis proksi individual IOS berbasis harga memiliki korelasi positif dengan realisasi pertumbuhan; c) menganalisis proksi individual IOS berbasis investasi memiliki korelasi positif dengan realisasi pertumbuhan. Dari hasil penelitiannya diperoleh beberapa hasil berikut: 1) Model gabungan proksi IOS dengan klasifikasi IOS memiliki kesesuaian dengan data sesungguhnya yang dapat dilihat dari nilai goodness of fit yang telah memenuhi syarat yang dianjurkan. Hal ini sesuai dengan yang diharapkan berdasarkan teori, bahwa setiap model pada structural equation models harus sesuai dengan data sesunguhnya dan kesesuaian tersebut dapat dilihat dari nilai goodness of fit nya; 2) Gabungan proksi individual IOS berbasis harga saham memiliki korelasi positif dengan realisasi pertumbuhan. Hal tersebut sesuai dengan teori yang menyatakan bahwa Proksi ini didasari pada anggapan yang menyatakan bahwa prospek pertumbuhan perusahaan secara parsial dinyatakan dalam harga-harga saham, dan perusahaan yang tumbuh akan memiliki nilai pasar yang lebih tinggi secara relatif untuk aset-aset yang dimiliki dibandingkan perusahaan yang tidak tumbuh; 3) Gabungan proksi individual IOS berbasis investasi memiliki korelasi positif dengan realisasi pertumbuhan. Dengan kata lain, proksi IOS berbasis Investasi memiliki korelasi yang positif. Hal ini juga sesuai dengan teori yang menyatakan bahwa bila proksi IOS berbasis investasi memiliki nilai korelasi yang positif terhadap realisasi pertumbuhan, maka banyak investor yang ingin menanamkan modalnya ke perusahaan tersebut karena investasi yang ditanamkan diharapkan akan memberikan return yang tinggi.

Berdasarkan uraian ini maka dapat disusun hipotesis sebagai berikut:

H1a: Perusahaan berpotensi tumbuh mempunyai rasio debt-to-equity lebih kecil daripada perusahaan tidak berpotensi tumbuh.

H1b: Perusahaan berpotensi tumbuh mempunyai rasio debt-to-total asset lebih kecil daripada perusahaan tidak berpotensi tumbuh.

H1c: Perusahaan berpotensi tumbuh memiliki profitabilitas yang lebih tinggi daripada perusahaan tidak berpotensi tumbuh.

H1d: Perusahaan berpotensi tumbuh lebih likuid daripada perusahaan tidak berpotensi tumbuh.

H2: Beta saham, size, profitabilitas, dan likuiditas berpengaruh signifikan terhadap struktur pendanaan perusahaan berpotensi tumbuh daripada perusahaan tidak berpotensi tumbuh. 


\section{METODOLOGI PENELITIAN}

\section{Populasi, dan Sampel}

Populasi dalam penelitian ini adalah perusahaan go publik yang terdaftar pada Bursa Efek Jakarta (BEJ). Pemilihan sampel dilakukan berdasarkan metode purposive sampling sesuai dengan kriteria yang telah ditentukan, yaitu:

(1) Sampel telah terdaftar pada BEJ sejak tahun 2007 atau sebelumnya.

(2) Sampel bukan perusahaan jenis industri perbankan dan keuangan lainnya, sesuai dengan pengklasifikasian Bursa Efek Jakarta.

(3) Sampel telah menerbitkan laporan keuangan selama empat tahun, yaitu tahun 2008-2011.

(4) Sampel mempunyai laporan tahunan yang berakhir pada tanggal 31 Desember. Hal ini dilakukan untuk menghindari adanya pengaruh waktu parsial dalam pengukuran variabel.

\section{Definisi Operasional Variabel}

Definisi operasional variabel yang ada dalam penelitian ini adalah sebagai berikut:

1. Set Kesempatan Investasi

a. Rasio nilai buku aset tetap pada nilai buku perusahaan [PPE/V]. $\mathrm{PPE} / \mathrm{V}=$ [nilai buku aset tetap]/[nilai buku perusahaan]

b. Rasio market to book value of equity [MVE/BE]. $\mathrm{MVE} / \mathrm{BVE}=$ [jumlah saham beredar $\mathrm{x}$ harga jual saham]/[total ekuitas]

c. Rasio earning to price $[\mathrm{E} / \mathrm{P}]$ $\mathrm{E} / \mathrm{P}=[$ laba bersih per saham (EPS)]: [harga jual saham]

d. Rasio market value of the firm to book value of assets [A/V]. $\mathrm{A} / \mathrm{V}=$ [total aset - total ekuitas + (saham beredar $\mathrm{x}$ harga jual saham) $] /[$ total aset]

e. Rasio tambahan modal saham pada nilai buku aset [CAP/A]. $\mathrm{CAP} / \mathrm{A}=$ [tambahan modal saham dalam tahun]/ [nilai buku aset]

2. Kebijakan Pendanaan Perusahaan

a. Debt to total asset ratio: Jumlah kewajiban / Total Aset

b. Debt to total equity ratio: Jumlah Kewajiban / Total Ekuitas

c. Long term debt to total asset: Jumlah kewajiban jangka panjang / Total Aset

d. Long term debt to total equity: Jumlah kewajiban jangka panjang / Total Ekuitas

3. Profitabilitas

a. Return On Investment : (EBIT + Penyusutan) / Total Aset

b. Return On Equity: Laba bersih / Total Ekuitas

c. Asset Turn Over: Laba bersih / Total Aset

d. EBITTA: EBIT / Total Aset

e. Net Profit Margin: Laba bersih / Penjualan

4. Likuiditas

a. Quick Asset to total asset: (Kas + Investasi Jk Pendek + Piutang) / Total Aset

b. Current ratio: Aset lancar / kewajiban lancar

5. Beta Saham: Model CAPM

6. Size: Log Total Aset 


\section{Analisis Data}

Prosedur analisis faktor digunakan untuk menyeleksi perusahaan yang berpotensi tumbuh dan tidak tumbuh. Penentuan perusahaan sebagai kelompok berpotensi atau tidak berpotensi tumbuh didasarkan pada penjumlahan indeks ketiga faktor tersebut (faktor1+faktor2+faktor3). Penjumlahan indeks (fac_sum) kemudian diperingkat mulai terbesar sampai terkecil. Kuartil pertama (25\% indeks tertinggi) merupakan kelompok perusahaan berpotensi tumbuh, sedangkan kuartil keempat (25\% indeks terendah) merupakan golongan perusahaan tidak berpotensi tumbuh. Hasil pengelompokan perusahaan menjadi perusahaan berpotensi tumbuh dan tidak berpotensi tumbuh akan diuji lagi validitasnya dengan t-test. Tujuan pengujian adalah untuk menjawab tujuan penelitian pertama. Uji signifikan $\mathrm{F}$ dan $\mathrm{t}$ dilakukan untuk mengetahui signifikansi pengaruh variabel independen (pertumbuhan perusahaan, profitabilitas, leverage, likuiditas, turn over performance, price earning ratio, dan earning per share) terhadap variabel dependen secara simultan dan parsial. Uji asumsi klasik dilakukan untuk memastikan bahwa model yang diperoleh benar-benar memenuhi asumsi dasar dalam analisis regresi yang meliputi asumsi: tidak terjadi multikolinearitas, dan tidak terjadi autokorelasi.

\section{HASIL DAN PEMBAHASAN}

\section{Hasil Analisis Faktor}

Pada penelitian ini, tiga faktor dibutuhkan untuk menjelaskan hubungan timbal balik antara proksi IOS. Untuk tahun 2008, faktor satu berkaitan dengan penambahan modal saham dan laba perusahaan. Loading masing-masing proksi IOS sebesar 0,9 dan 0,87 . Faktor kedua berkaitan dengan penggunaan aset tetap dan harga pasar aset perusahaan dengan loading masing-masing 0,79 dan 0,73. Faktor ketiga berkaitan dengan nilai pasar ekuitas dengan loading sebesar 0,98.

Untuk tahun 2008, faktor satu berkaitan dengan penambahan modal saham dan laba perusahaan. Loading masing-masing proksi IOS sebesar 0,9 dan 0,87. Faktor kedua berkaitan dengan penggunaan aset tetap dan harga pasar aset perusahaan dengan loading masing-masing 0,79 dan 0,73. Faktor ketiga berkaitan dengan nilai pasar ekuitas dengan loading sebesar 0,98. Pada tahun 2009, faktor satu berkaitan dengan nilai buku aset tetap dan nilai pasar aset dengan loading faktor proksi masing-masing adalah 0,73 dan 0,61 . Selanjutnya factor kedua berhubungan dengan nilai buku aset tetap dan tambahan modal saham dengan loading faktor masing-masing sebesar 0,2 dan 0,97. Sementara untuk faktor 3, berhubungan dengan nilai buku aset tetap dan nilai pasar ekuitas. Selanjutnya informasi lebih lengkap perihal loading faktor dapat dilihat pada tabel tabel 1.

Tabel 1.

Matrik Rotasi Komponen

\begin{tabular}{llccc}
\hline Periode & Proksi IOS & Factor1 & Factor2 & Factor3 \\
\hline \multirow{2}{*}{2008} & PPE_BVA & 0.04 & $\mathbf{0 . 7 9}$ & 0.17 \\
& MVE_BVE & -0.02 & 0.00 & $\mathbf{0 . 9 8}$ \\
& MVA_BVA & -0.09 & $\mathbf{0 . 7 3}$ & -0.17 \\
& CAP_BVA & $\mathbf{0 . 9 0}$ & 0.10 & 0.00 \\
\hline
\end{tabular}




\begin{tabular}{llccc}
\hline \multirow{2}{*}{2009} & EP & $\mathbf{0 . 8 7}$ & -0.17 & -0.02 \\
& PPE_BVA & $\mathbf{0 . 7 3}$ & $\mathbf{0 . 2 0}$ & $\mathbf{0 . 1 7}$ \\
& MVE_BVE & -0.02 & -0.03 & $\mathbf{0 . 9 8}$ \\
& MVA_BVA & $\mathbf{0 . 6 1}$ & -0.20 & -0.13 \\
& CAP_BVA & -0.01 & $\mathbf{0 . 9 7}$ & -0.03 \\
& EP & -0.66 & 0.01 & 0.04 \\
& PPE_BVA & $\mathbf{0 . 7 5}$ & 0.21 & 0.23 \\
2010 & MVE_BVE & 0.05 & -0.07 & $\mathbf{0 . 9 3}$ \\
& MVA_BVA & $\mathbf{0 . 7 3}$ & -0.16 & -0.12 \\
& CAP_BVA & 0.10 & $\mathbf{0 . 8 8}$ & -0.15 \\
& EP & -0.35 & $\mathbf{0 . 4 4}$ & $\mathbf{0 . 2 9}$ \\
& PPE_BVA & $\mathbf{0 . 7 2}$ & 0.29 & -0.12 \\
& MVE_BVE & -0.01 & 0.03 & $\mathbf{0 . 9 8}$ \\
& MVA_BVA & 0.83 & -0.18 & 0.10 \\
& CAP_BVA & 0.04 & $\mathbf{0 . 7 2}$ & 0.11 \\
& EP & -0.01 & -0.70 & 0.08 \\
\hline
\end{tabular}

Sumber: Hasil Olah Data

\section{Hasil Uji Asumsi Klasik}

Berdasarkan kriteria tolerance dan VIF (lihat tabel 5 dan 6), diperoleh kesimpulan tidak terjadi gejala multikolinearitas pada seluruh model persamaan regresi berganda. Selanjutnya berdasarkan uji durbin-watson, juga diperoleh kesimpulan bahwa memang masih terjadi gejala autokorelasi pada beberapa persamaan regresi berganda (baik pada persamaan untuk klasifikasi perusahaan yang berpotensi tumbuh dan tidak berpotensi tumbuh).

\section{PEMBAHASAN}

Kecuali pada DER, size, dan beta saham, secara umum, memang terjadi perbedaan pada seluruh proksi (leverage, profitabilitas, likuiditas) antara perusahaan yang berpotensi tumbuh dan tidak tumbuh. Hasil temuan ini tidak mendukung penelitian Yanto (2012), karena berdasarkan tabel 2, diperoleh hasil bahwa ternyata tidak ada perbedaan signifikan pada rasio debt to equity antara perusahaan yang berpotensi tumbuh dan tidak tumbuh. Begitu juga mengenai keterkaitan unsystematic risk dengan IOS, untuk kasus Indonesia, selama periode 2008-2011 tidak ada perbedaan signifikan yang terjadi antara keterkaitan dua hal tersebut.

Untuk proksi debt to total asset, current rasio merupakan variabel yang berpengaruh signifikan terhadap struktur pendanaan perusahaan yang tidak berpotensi tumbuh, sedangkan untuk perusahaan yang berpotensi tumbuh, ROI, EBITTA dan NPM merupakan variabel yang berpengaruh signifikan terhadap struktur pendanaannya. Pada proksi debt to equity, ROE adalah variabel yang berpengaruh signifikan secara parsial, baik pada perusahaan yang berpotensi tumbuh dan tidak berpotensi tumbuh. Untuk model debt to total asset, current ratio merupakan variabel yang memiliki pengaruh signifikan secara parsial terhadap struktur pendanaan emiten, khususnya yang tidak berpotensi tumbuh sedangkan bagi perusahaan yang berpotensi tumbuh unsystematic risk dan profitabilitas lebih berpengaruh dibanding likuiditas. 
Secara parsial (lihat Tabel 3), untuk keseluruhan model persamaan, size berpengaruh signifikan terhadap struktur pendanaan perusahaan yang tidak berpotensi tumbuh pada tahun 2009. Sedangkan ROE secara parsial berpengaruh signifikan terhadap struktur pendanaan seluruh model persamaan pada 2010 untuk perusahaan yang tidak berpotensi tumbuh. Rasio EBITTA secara parsial berpengaruh signifikan terhadap struktur pendanaan seluruh model persamaan pada 2011 baik bagi perusahaan yang tidak berpotensi tumbuh dan yang berpotensi tumbuh. Dari hasil uji hipotesis tersebut juga diperoleh beberapa hasil yang sangat menarik untuk dicermati: untuk proksi struktur pendanaan DTA dan LDTA, selama periode penelitian ternyata profitabilitas (ROI, ROE, EBITTA, dan NPM) tidak berpengaruh signifikan baik bagi emiten yang berpotensi tumbuh atau tidak. Demikian juga halnya dengan likuiditas (QATA dan CATA), ternyata kapasitas emiten dalam memenuhi kewajiban jangka pendeknya secara umum tidak berpengaruh signifikan terhadap struktur pendanaan.

Sementara pada proksi IOS DER dan LDER, profitabilitas emiten pada periode 2009 dan 2010 secara umum tidak berpengaruh signifikan terhadap struktur pendanaan baik pada emiten yang berpotensi tumbuh atau tidak. Demikian juga halnya dengan likuiditas (QATA dan CACL) juga berpengaruh signifikan terhadap struktur pendanaan emiten. Temuan menarik lainnya yakni, risiko sistematik emiten ternyata juga tidak berpengaruh signifikan terhadap struktur pendanaan emiten (baik yang berpotensi tumbuh atau pun tidak), hasil ini mendukung penelitian Purnomo (2005) dan Puspitasari, dan Gumanti (2005).

Secara simultan seluruh proksi yang digunakan berpengaruh signifikan terhadap struktur pendanaan perusahaan, baik itu yang berpotensi tumbuh dan yang tidak berpotensi tumbuh (lihat tabel 3). Hasil temuan empiris ini sukar untuk dilakukan komparasi dengan penelitian terdahulu perihal positioning proksi set kesempatan, metode pengklasifikasian sampel dan tujuan penelitian yang berbeda.

\section{Koefisien Determinasi}

Kemampuan proksi profitabilitas, likuiditas, size dan beta saham dalam menjelaskan variansi struktur pendanaan perusahaan yang berpotensi tumbuh dan tidak berpotensi tumbuh sangat variatif. Untuk perusahaan yang berpotensi tidak tumbuh range kemampuan proksi adalah 6,05\%-98,96\% untuk seluruh model persamaan, sedangkan pada perusahaan yang berpotensi tumbuh kisaran kemampuan proksi dalam menjelaskan variansi struktur pendanaan perusahaan adalah: $5,46 \%-97,46 \%$.

\section{SIMPULAN DAN SARAN Simpulan}

Penelitian ini bertujuan untuk memberi bukti tambahan atas eksistensi teori IOS dalam kaitannya dengan kebijakan pendanaan pada pasar modal yang sedang berkembang khususnya pada Bursa Efek Indonesia dan menghitung pengaruh beta saham, size, profitabilitas, dan likuiditas terhadap struktur pendanaan emiten yang berpotensi tumbuh dan tidak tumbuh. Dari hasil uji hipotesis pertama dapat disimpulkan bahwa kecuali pada debt equity ratio, size, dan beta saham, secara umum, memang terjadi perbedaan pada seluruh proksi 
(leverage, profitabilitas, likuiditas) antara perusahaan yang berpotensi tumbuh dan tidak tumbuh. Hasil empiris uji hipotesis kedua menyatakan bahwa, secara simultan seluruh proksi yang digunakan berpengaruh signifikan terhadap struktur pendanaan perusahaan, baik itu yang berpotensi tumbuh dan yang tidak berpotensi tumbuh untuk seluruh periode penelitian.

\section{Saran}

Adapun beberapa saran untuk memperluas topik penelitian ini di masa mendatang adalah sebagai berikut:

1. Penelitian selanjutnya agar menambahkan periode penelitian untuk lebih mengetahui secara lebih komprehensif konsistensi implikasi IOS terhadap pertumbuhan perusahaan dan hubungan IOS dengan kebijakan pendanaan perusahaan.

2. Penggunaan variabel IOS dapat dikembangkan dengan menggunakan variable-variabel lain yang tidak terungkap di dalam penelitian ini. Misalnya mempertimbangkan intangible value added yang bisa mewakili keunggulan kompetitif emiten, sepeti intellectual capital. 


\section{DAFTAR PUSTAKA}

Abor, and Bokpin, G,. 2010. Investment Opportunities, Corporate Finance, and Dividend Payout Policy: Evidence from emerging markets. Studies in Economics and Finance, vol. 27, no. 3, pp. 180-194.

Adam, T., and Goyal, V. K. (2008). The Investment Opportunity Set and Its Proxy Variables. The Journal of Financial Research, 31 (1), 41-63.

Adriani, Irma. 2011. Pengaruh Investment Opportunity Set dan Mekanisme Corporate Governance terhadap Kualitas Laba dan Nilai Perusahaan (Studi Pada Perusahaan Manufaktur yang terdaftar Di Bursa Efek Indonesia Tahun 2005-2009). Kertas Kerja, Fakultas Ekonomika dan Bisnis UNDIP, Semarang.

Aini, Nurul. 2010. Asosiasi Set Kesempatan Investasi Dengan Kebijakan Pendanaan dan Dividen Perusahaan. Kertas Kerja, University of Muhammadiyah Malang.

Akibar. 2011. Gabungan Proksi Invesment Opportunity Set dan Hubungannya terhadap Realisasi Pertumbuhan dengan Pendekatan Analisis Faktor Konfirmatori (Studi Empirik pada Perusahaan Manufaktur yang terdaftar di BEI) Periode 2006-2009. Kertas Kerja, UIN Syarif Hidayatullah, Jakarta

Andriyani, Maria. 2008. Analisis Cash Ratio, Debt to Equity Ratio, Insider Ownership, Investment Opportunity Set, dan Profitability terhadap Kebijakan Dividen (Studi Empiris pada Perusahaan Otomotif Di Bursa Efek Indonesia Periode Tahun 2004-2006). Tesis, Program Pascasarjana Universitas Diponegoro, Semarang.

Baker, M. and J. Wurgler. 2002. Market Timing and Capital Structure, Journal of Finance 57,1-32.

Barus, Irene Sukma Lestari. 2008 Pengaruh Investment Opportunity Set Terhadap Pertumbuhan Perusahaan Dan Return Saham Pada Perusahaan Manufaktur yang terdaftar Di Bursa Efek Jakarta (Periode Penelitian 2005- 2007). Kertas Kerja, USU, Medan.

Batubara, Lintas Andriadi. 2012. Pengaruh Investment Opportunity Set, Return On Investment, dan Net Profit Margin terhadap Devidend Payout Ratio pada Perusahaan Manufaktur Di Bursa Efek Indonesia Periode 2008-2010. Kertas Kerja, USU, Medan.

Bintary, Dewi. 2008. Perbedaan Tingkat Leverage, Kebijakan Dividen dan Perubahan Harga Saham pada Perusahaan Tumbuh dan Tidak Tumbuh dengan Pendekatan Pertumbuhan Laba. Kertas Kerja, STIE Perbanas, Surabaya.

Brigham, Eugene F dan Houston, Joel F. 2006. Manajemen Keuangan. Buku 1 dan 2. Edisi Kesepuluh. Alih Bahasa Ali Akbar Yulianto. Jakarta: Erlangga.

Dachi, Leny S. 2010. Pengaruh Profitability dan Investment Opportunity Set terhadap Dividen Kas pada Perusahaan Manufaktur Di Bursa Efek Indonesia. Kertas Kerja, USU, Medan.

Gultom, Selfi Afriani. 2011. Analisis Pengaruh Free Cash Flow dan Struktur Kepemilikan Saham terhadap Kebijakan Utang Dengan Investment 
Opportunity Set sebagai Variabel Moderating pada Perusahaan Manufaktur Di Indonesia. Tesis, Program Pascasarjana, USU, Medan.

Gusrifa, Rahmad. 2007. Pengaruh Investment Oportunity Set terhadap Volume Perdagangan Saham Perusahaan Go Public Di Bursa Efek Jakarta. Tesis, Program Pascasarjana, USU, Medan.

Husnan, Suad. 2005. Dasar Dasar Teori Portofolio Dan Analisis Sekuritas. Yogyakarta: Unit Penerbit dan Percetakan AMP YKPN.

Iturriaga, F. J. L., and Crisostomo, V. L. (2010). Do leverage, dividend payout, and ownership concentration influence firms' value creation? An analysis of Brazilian firms. Emerging Markets Finance and Trade , 46 (3), 80-94.

Jogiyanto, Hartono. 2009. Teori Portofolio dan Analisis Investasi. Yogyakarta: BPFE-YOGYAKARTA.

Kumar, Suwendra. 2007. Analisis Pengaruh Struktur Kepemilikan, Investment Opportunity Set, dan Rasio-Rasio Keuangan terhadap Dividend Payout Ratio (Studi Komparatif pada perusahaan PMA dan PMDN di Bursa Efek Jakarta Periode Tahun 2003-2005). Tesis, Program Pascasarjana, Universitas Diponegoro, Semarang

Kurniasi, Ninik dan Susan Andriana. 2011. Pengaruh Dividend Yield dan Price Earnings Ratio terhadap Return Saham pada Level Investment Opportunity Set Yang Berbeda (Studi pada Saham LQ 45 yang Tercatat di BEI). Jurnal Eksos, Vol. 7. N0. 1 Jan. ISSN 1693-9093

Martati, Indah. 2010. Asosiasi Kebijakan Pendanaan dan Investment Opportunity Set Perusahaan Manfaktur Yang Listed Di Bursa Efek Indonesia. Jurnal Administrasi Bisnis, 7 (1). pp. 1-7.

Mindania. 2013. Pengaruh Rasio Keuangan Dan Investment Opportunity Set (IOS) terhadap Harga Saham pada Industri Konsumsi yang terdaftar Di Bursa Efek Indonesia. Kertas Kerja, USU, Medan

Mulyono, Budi. 2009. Pengaruh Debt Equity Ratio, Insider Ownership, Size, Dan Investment Opportunity Set. Tesis, Program Pascasarjana, UNDIP

Mutiah, Wikky Nalaprayoga. 2012. Analisis Pengaruh Kepemilikan Manajerial, Investment Opportunity Set, Free Cash Flow, dan Ukuran Perusahaan terhadap Kebijakan Hutang pada Perusahaan Manufaktur yang Terdaftar pada Bursa Efek Indonesia (BEI). Kertas Kerja, USU, Medan.

Nugraha, Dimas Adi dan Sampurno, R Djoko. 2012. Analisis Pengaruh Insider Ownership, Debt to Equity Ratio, Return On Equity, Firm Size dan Investment Opportunity Set Terhadap Dividend Payout Ratio (Studi Kasus pada Perusahaan Manufaktur yang terdaftar di Bursa Efek Indonesia Tahun 2007-2010). Kertas Kerja, Fakultas Ekonomika dan Bisnis UNDIP, Semarang.

Pasaribu, Dethy Mathilda. 2012. Analisis Pengaruh Free Cash Flow, Kepemilikan Manajerial, Set Kesempatan Investasi, dan Ukuran Perusahaan terhadap Kebijakan Hutang pada Perusahaan Manufaktur yang terdaftar di Bursa Efek Indonesia. Kertas Kerja, USU, Medan.

Prapaska, Johan Ruth. 2012. Analisis Pengaruh Tingkat Profitabilitas, Keputusan Investasi, Keputusan Pendanaan, Dan Kebijakan Dividen Terhadap Nilai 
Perusahaan Pada Perusahaan Manufaktur Di BEI Tahun 2009-2010. Kertas Kerja, Fakultas Ekonomika dan Bisnis UNDIP, Semarang.

Purnomo, Yohanes Sidik. 2005. Asosiasi Proksi Investment Opportunity Set dengan Leverage, Beta, dan ROA: Bukti Empiris Dari Bursa Efek Jakarta. Tesis, Program Pascasarjana UNIKA SOEGIJAPRANATA.

Puspitasari, Novi dan Gumanti, Tatang Ary. 2005. Investment Opportunity Set, Risiko dan Kinerja Finansial Dalam Tahapan Siklus Kehidupan Perusahaan Publik Di Indonesia Tahun 1999-2003. Simposium Riset Ekonomi II, Surabaya, 23-24 November.

Puspitasari, Novi. 2012. Kinerja Finansial dan Kesempatan Investasi Perusahaan Bertumbuhan dan Tidak Bertumbuh. Bisma Jurnal Bisnis dan Manajemen Vol.6, No.1, Januari.

Puteri, Paramitha Anggia dan Rohman, Abdul. 2012. Analisis Pengaruh Investment Opportunity Set dan Mekanisme Corporate Governance terhadap Kualitas Laba dan Nilai Perusahaan. Kertas Kerja, UNDIP, Semarang.

Putra, Yan Permana. 2013. Pengaruh Struktur Kepemilikan, Kebijakan Dividen, Investment Opportunity Set, Dan Corporate Governance terhadap Nilai Perusahaan pada Perusahaan Manufaktur yang terdaftar Di Bursa Efek Indonesia. Kertas Kerja, UPN Veteran, Yogyakarta.

Putri, Arie Pratania. 2011. Pengaruh Investment Opportunity Set dan Profitabilitas terhadap Return Saham dan Kebijakan Dividen pada Perusahaan Manufaktur yang Terdaftar di Bursa Efek Indonesia. Kertas Kerja, USU, Medan.

Rachman, Arief. 2010. Pengaruh Investment Opportunity Set dan New Business Development terhadap Profitabilitas (Studi Empiris pada Perusahaan Manufaktur Yang Terdaftar Di Bursa Efek Indonesia). Kertas Kerja, USU, Medan.

Suharli, Michell. 2006. Pengaruh Profitability dan Investment Opportunity Set terhadap Kebijakan Dividen Tunai dengan Likuiditas sebagai Variabel Penguat (Studi Pada Perusahaan Manufaktur Bursa Efek Indonesia 2002-2003). Jurnal Akuntansi dan Keuangan Vol. 9, No. 1,

Susilo, Andi. 2011. Analisis Pengaruh Struktur Kepemilikan, Investment Opportunity Set, Rasio-Rasio Keuangan, dan Cash Flow terhadap Dividend Payout Ratio (Studi di Bursa Efek Indonesia Periode Tahun 2006-2008). Tesis, Program Pascasarjana UNDIP, Semarang.

Tjandra, Ronowati. 2005. Pengaruh Investment Opportunity Set Terhadap Kebijakan Dividen Dengan Pemoderasi Pilihan Prosedur Akuntansi Pada Perusahaan Yang Go-Public Di Bursa Efek Jakarta. Jurnal Bisnis dan Manajemen, Vol.5 No.1

Wardani, Rima Aguatania Kusuma dan Baldric Siregar. 2009 Pengaruh Aliran Kas Bebas terhadap Nilai Pemegang Saham dengan Kesempatan Investasi dan Dividen sebagai Variabel Moderator. Jurnal Akuntansi dan Manajemen, Vol.20 No.3 Desember, ISSN: 0853-1259.

Welch, Ivo. 2004. Capital Structure and Stock Returns, Journal of Political Economy, 112, 106-131. 
Wijayanto, Andi. 2011. Analisis Asosiasi Proksi Investment Opportunity Set, Kebijakan Pendanaan, dan Kebijakan Dividen pada Perusahaan Food and Beverages Di Indonesia. Jurnal Ilmu Sosial. ISSN 1411-8254.

Wisudha, Pandu Fajar. 2007. Analisis Pengaruh Dividen Dan Aliran Kas Bebas Terhadap Leverage Perusahaan dengan Moderasi Set Kesempatan Investasi. Jurnal Ekonomi dan Bisnis, Vol.5 No.2 Juli.

Yanto. 2012. Analisis Perbedaan Kebijakan Pendanaan dan Dividen antara Perusahaan Tumbuh dan Tidak Tumbuh Pada Bursa Efek Indonesia dengan Pendekatan Asosiasi Proksi Investment Opportunity Set (Studi pada Perusahaan Manufaktur yang Terdaftar Di Bursa Efek Indonesia Periode 2006-2009). Kertas Kerja, Fakultas Ekonomika dan Bisnis UNDIP, Semarang.

Yulianti, Emi. 2007. Hubungan Investment Opportunity Set dengan Realisasi Pertumbuhan Serta Perbedaan Perusahaan Tumbuh dan Tidak Tumbuh terhadap Kebijakan Pendanaan dan Dividen pada Perusahaan Yang Go Public. Kertas Kerja.

Zahrotus, Syarif dan Zuhrotun. 2009. Pengaruh Kebijakan Pendanaan, Kebijakan Dividen, Dan Profitabilitas terhadap Investment Opportunity Set Perusahaan Publik Manufaktur. Buletin Ekonomi Vol. 7, No. 2, Desember. 
Tabel 2. Hasil Uji Beda Rata-rata

\begin{tabular}{|c|c|c|c|c|c|c|c|c|c|c|c|c|c|}
\hline & Beta & Size & DTA & DER & LDTA & LDER & ROI & ROE & ATO & EBITTA & NPM & QATA & CACL \\
\hline \multicolumn{14}{|c|}{2008} \\
\hline $\mathrm{F}$ & 0.061 & 8.492 & 0.200 & 3.791 & 2.153 & 3.652 & 4.394 & 3.826 & 0.546 & 5.979 & 2.676 & 32.649 & 2.490 \\
\hline Sig. & 0.805 & 0.004 & 0.656 & 0.054 & 0.145 & 0.059 & 0.038 & 0.053 & 0.462 & 0.016 & 0.105 & 0.000 & 0.118 \\
\hline Sig. (2-tailed) & 0.297 & 0.136 & 0.007 & 0.322 & 0.000 & 0.305 & 0.000 & 0.340 & 0.478 & 0.580 & 0.249 & 0.000 & 0.501 \\
\hline \multicolumn{14}{|l|}{ Mean } \\
\hline Difference & -0.350 & -0.706 & -0.180 & -62.184 & -0.204 & -27.447 & -0.177 & -0.499 & 0.013 & 0.010 & -0.938 & 0.259 & -6.130 \\
\hline $\mathrm{F}$ & 0.000 & 2.923 & 1.813 & 0.005 & 4.400 & 0.777 & 8.196 & 3.867 & 1.615 & 0.000 & 8.080 & 16.866 & 3.017 \\
\hline Sig. & 0.992 & 0.090 & 0.181 & 0.945 & 0.038 & 0.380 & 0.005 & 0.052 & 0.206 & 0.991 & 0.005 & 0.000 & 0.085 \\
\hline $\mathrm{t}$ & 0.852 & -2.231 & -2.567 & -0.833 & -3.933 & -1.170 & -1.751 & 2.321 & 3.890 & 3.031 & 2.607 & 8.507 & -0.773 \\
\hline Sig. (2-tailed) & 0.396 & 0.028 & 0.012 & 0.407 & 0.000 & 0.245 & 0.083 & 0.022 & 0.000 & 0.003 & 0.010 & 0.000 & 0.441 \\
\hline \multicolumn{14}{|l|}{ Mean } \\
\hline Difference & 0.229 & -0.813 & -0.201 & -1.190 & -0.168 & -0.814 & -0.091 & 0.409 & 0.108 & 0.070 & 0.328 & 0.262 & -7.851 \\
\hline \multicolumn{14}{|c|}{2010} \\
\hline $\mathrm{F}$ & 2.314 & 6.988 & 1.897 & 0.154 & 6.243 & 1.629 & 5.653 & 0.008 & 0.127 & 0.013 & 2.170 & 42.238 & 3.074 \\
\hline $\mathrm{t}$ & 1.135 & -1.348 & -0.144 & -0.557 & -5.150 & -1.414 & -2.255 & -0.160 & 0.031 & 0.088 & -0.889 & 5.859 & 1.326 \\
\hline Sig. (2-tailed) & 0.259 & 0.180 & 0.886 & 0.579 & 0.000 & 0.160 & 0.026 & 0.873 & 0.975 & 0.930 & 0.376 & 0.000 & 0.188 \\
\hline \multicolumn{14}{|l|}{ Mean } \\
\hline Difference & 0.870 & -0.620 & -0.010 & -0.825 & -0.197 & -1.249 & -0.124 & -0.021 & 0.001 & 0.002 & -0.374 & 0.195 & 1.444 \\
\hline \multicolumn{14}{|c|}{2011} \\
\hline $\mathrm{F}$ & 0.057 & 8.844 & 0.028 & 0.070 & 9.302 & 0.367 & 2.372 & 0.627 & 6.280 & 5.488 & 5.525 & 42.502 & 16.487 \\
\hline Sig. & 0.811 & 0.004 & 0.868 & 0.792 & 0.003 & 0.546 & 0.126 & 0.430 & 0.014 & 0.021 & 0.021 & 0.000 & 0.000 \\
\hline $\mathrm{t}$ & -0.254 & -1.474 & -2.098 & 0.118 & -5.556 & -0.328 & -1.860 & 1.675 & 2.691 & 2.874 & 1.285 & 7.943 & 2.986 \\
\hline Sig. (2-tailed) & 0.800 & 0.143 & 0.038 & 0.907 & 0.000 & 0.743 & 0.066 & 0.097 & 0.008 & 0.005 & 0.202 & 0.000 & 0.004 \\
\hline Mean & & & & & & & & & & & & & \\
\hline Difference & -0.079 & -0.681 & -0.185 & 2.938 & -0.201 & -4.870 & -0.111 & 1.319 & 0.066 & 0.072 & 1.104 & 0.261 & 2.784 \\
\hline
\end{tabular}

Sumber : Hasil Olah Data 
Tabel 3. Hasil Uji Signifikansi Simultan dan Parsial

\begin{tabular}{|c|c|c|c|c|c|c|c|c|c|c|c|c|}
\hline \multirow{2}{*}{ Model } & \multirow{2}{*}{$\begin{array}{c}\text { Proksi } \\
\text { IOS }\end{array}$} & \multirow{2}{*}{ Koefisien } & 2008 & 2009 & 2010 & 2011 & \multirow{2}{*}{ Model } & \multirow{2}{*}{$\begin{array}{l}\text { Proksi } \\
\text { IOS }\end{array}$} & 2008 & 2009 & 2010 & 2011 \\
\hline & & & \multicolumn{4}{|c|}{ Sig.t } & & & \multicolumn{4}{|c|}{ Sig.t } \\
\hline \multirow{18}{*}{ DTA } & \multirow{9}{*}{$\begin{array}{c}\text { Tidak } \\
\text { Berpotensi } \\
\text { Tumbuh }\end{array}$} & Beta & 0.290 & 0.566 & 0.774 & 0.845 & \multirow{18}{*}{ LDTA } & \multirow{9}{*}{$\begin{array}{c}\text { Tidak } \\
\text { Berpotensi } \\
\text { Tumbuh }\end{array}$} & 0.142 & 0.617 & 0.963 & 0.552 \\
\hline & & Size & 0.010 & 0.311 & 0.536 & 0.818 & & & 0.003 & 0.000 & 0.080 & 0.106 \\
\hline & & ROI & 0.462 & 0.927 & 0.188 & 0.636 & & & 0.148 & 0.356 & 0.813 & 0.994 \\
\hline & & ROE & 0.418 & 0.453 & 0.264 & 0.434 & & & 0.596 & 0.211 & 0.582 & 0.191 \\
\hline & & EBITTA & 0.264 & 0.248 & 0.001 & 0.042 & & & 0.05 & 0.859 & 0.601 & 0.014 \\
\hline & & NPM & 0.237 & 0.165 & 0.537 & 0.354 & & & 0.717 & 0.179 & 0.905 & 0.836 \\
\hline & & QATA & 0.713 & 0.498 & 0.722 & 0.692 & & & 0.282 & 0.037 & 0.551 & 0.300 \\
\hline & & CACL & 0.002 & 0.010 & 0.031 & 0.076 & & & 0.939 & 0.568 & 0.813 & 0.045 \\
\hline & & Sig.F & 0.000 & 0.010 & 0.005 & 0.092 & & & 0.000 & 0.010 & 0.005 & 0.092 \\
\hline & \multirow{9}{*}{$\begin{array}{l}\text { Berpotensi } \\
\text { Tumbuh }\end{array}$} & Beta & 0.101 & 0.044 & 0.057 & 0.633 & & \multirow{9}{*}{$\begin{array}{c}\text { Berpotensi } \\
\text { Tumbuh }\end{array}$} & 0.481 & 0.776 & 0.865 & 0.926 \\
\hline & & Size & 0.551 & 0.065 & 0.504 & 0.892 & & & 0.939 & 0.586 & 0.734 & 0.725 \\
\hline & & ROI & 0.706 & 0.164 & 0.006 & 0.010 & & & 0.398 & 0.652 & 0.159 & 0.092 \\
\hline & & ROE & 0.714 & 0.219 & 0.002 & 0.986 & & & 0.287 & 0.819 & 0.064 & 0.066 \\
\hline & & EBITTA & 0.292 & 0.491 & 0.001 & 0.006 & & & 0.392 & 0.439 & 0.404 & 0.463 \\
\hline & & NPM & 0.529 & 0.037 & 0.376 & 0.015 & & & 0.016 & 0.714 & 0.444 & 0.038 \\
\hline & & QATA & 0.084 & 0.043 & 0.280 & 0.945 & & & 0.505 & 0.384 & 0.031 & 0.300 \\
\hline & & CACL & 0.392 & 0.820 & 0.467 & 0.038 & & & 0.839 & 0.390 & 0.378 & 0.047 \\
\hline & & Sig.F & 0.360 & 0.022 & 0.000 & 0.000 & & & 0.360 & 0.022 & 0.000 & 0.000 \\
\hline \multirow{2}{*}{ Model } & \multirow{2}{*}{$\begin{array}{l}\text { Proksi } \\
\text { IOS }\end{array}$} & \multirow{2}{*}{ Koefisien } & 2008 & 2009 & 2010 & 2011 & \multirow{2}{*}{ Model } & \multirow{2}{*}{$\begin{array}{c}\text { Proksi } \\
\text { IOS }\end{array}$} & 2008 & 2009 & 2010 & 2011 \\
\hline & & & & $\mathrm{Si}$ & & & & & \multicolumn{4}{|c|}{ Sig.t } \\
\hline \multirow{18}{*}{ DER } & \multirow{18}{*}{$\begin{array}{c}\text { Berpotensi } \\
\text { Tumbuh }\end{array}$} & Beta & 0.049 & 0.382 & 0.819 & 0.637 & \multirow{18}{*}{ LDER } & \multirow{9}{*}{$\begin{array}{c}\text { Tidak } \\
\text { Berpotensi } \\
\text { Tumbuh }\end{array}$} & 0.048 & 0.775 & 0.985 & 0.734 \\
\hline & & Size & 0.091 & 0.512 & 0.294 & 0.155 & & & 0.097 & 0.355 & 0.231 & 0.150 \\
\hline & & ROI & 0.047 & 0.517 & 0.115 & 0.000 & & & 0.039 & 0.870 & 0.902 & 0.000 \\
\hline & & ROE & 0.000 & 0.000 & 0.724 & 0.000 & & & 0.000 & 0.191 & 0.438 & 0.000 \\
\hline & & EBITTA & 0.000 & 0.641 & 0.623 & 0.000 & & & 0.000 & 0.875 & 0.588 & 0.001 \\
\hline & & NPM & 0.001 & 1.000 & 0.730 & 0.417 & & & 0.002 & 0.871 & 0.951 & 0.471 \\
\hline & & QATA & 0.416 & 0.028 & 0.212 & 0.440 & & & 0.428 & 0.043 & 0.413 & 0.285 \\
\hline & & CACL & 0.993 & 0.671 & 0.444 & 0.344 & & & 0.932 & 0.751 & 0.481 & 0.533 \\
\hline & & Sig.F & 0.000 & 0.003 & 0.650 & 0.000 & & & 0.000 & 0.296 & 0.931 & 0.000 \\
\hline & & Beta & 0.895 & 0.681 & 0.461 & 0.941 & & & 0.911 & 0.762 & 0.483 & 0.844 \\
\hline & & Size & 0.001 & 0.915 & 0.597 & 0.467 & & & 0.001 & 0.944 & 0.608 & 0.509 \\
\hline & & ROI & 0.451 & 0.310 & 0.352 & 0.917 & & & 0.428 & 0.437 & 0.413 & 0.860 \\
\hline & & ROE & 0.753 & 0.000 & 0.000 & 0.000 & & & 0.460 & 0.146 & 0.000 & 0.000 \\
\hline & & EBITTA & 0.963 & 0.115 & 0.206 & 0.000 & & Berpotensi & 0.902 & 0.608 & 0.257 & 0.000 \\
\hline & & NPM & 0.857 & 0.880 & 0.723 & 0.838 & & Tumbuh & 0.920 & 0.974 & 0.912 & 0.859 \\
\hline & & QATA & 0.779 & 0.766 & 0.683 & 0.532 & & & 0.871 & 0.896 & 0.916 & 0.516 \\
\hline & & CACL & 0.890 & 0.967 & 0.937 & 0.223 & & & 0.912 & 0.919 & 0.813 & 0.259 \\
\hline & & Sig.F & 0.140 & 0.027 & 0.000 & 0.000 & & & 0.129 & 0.949 & 0.000 & 0.000 \\
\hline
\end{tabular}


Tabel 4. Koefisien Determinasi

\begin{tabular}{|c|c|c|c|c|c|c|c|}
\hline Model & Periode & IOS & $\mathbf{R}^{2}$ & Model & Periode & IOS & $\mathbf{R}^{2}$ \\
\hline \multirow{8}{*}{ DTA } & \multirow[t]{2}{*}{2008} & $\begin{array}{l}\text { Tidak Berpotensi } \\
\text { Tumbuh }\end{array}$ & $47.02 \%$ & \multirow{8}{*}{ LDTA } & \multirow{2}{*}{2008} & $\begin{array}{l}\text { Tidak Berpotensi } \\
\text { Tumbuh }\end{array}$ & $36.90 \%$ \\
\hline & & Berpotensi Tumbuh & $16.46 \%$ & & & Berpotensi Tumbuh & $21.02 \%$ \\
\hline & \multirow{2}{*}{2009} & $\begin{array}{l}\text { Tidak Berpotensi } \\
\text { Tumbuh }\end{array}$ & $33.69 \%$ & & \multirow{2}{*}{2009} & $\begin{array}{l}\text { Tidak Berpotensi } \\
\text { Tumbuh }\end{array}$ & $47.62 \%$ \\
\hline & & Berpotensi Tumbuh & $30.68 \%$ & & & Berpotensi Tumbuh & $7.73 \%$ \\
\hline & \multirow[t]{2}{*}{2010} & $\begin{array}{l}\text { Tidak Berpotensi } \\
\text { Tumbuh }\end{array}$ & $35.93 \%$ & & \multirow[t]{2}{*}{2010} & $\begin{array}{l}\text { Tidak Berpotensi } \\
\text { Tumbuh }\end{array}$ & $11.02 \%$ \\
\hline & & Berpotensi Tumbuh & $49.38 \%$ & & & Berpotensi Tumbuh & $18.33 \%$ \\
\hline & \multirow[t]{2}{*}{2011} & $\begin{array}{l}\text { Tidak Berpotensi } \\
\text { Tumbuh }\end{array}$ & $24.76 \%$ & & \multirow[t]{2}{*}{2011} & $\begin{array}{l}\text { Tidak Berpotensi } \\
\text { Tumbuh }\end{array}$ & $31.82 \%$ \\
\hline & & Berpotensi Tumbuh & $44.73 \%$ & & & Berpotensi Tumbuh & $28.08 \%$ \\
\hline \multirow{8}{*}{ DER } & \multirow[t]{2}{*}{2008} & $\begin{array}{l}\text { Tidak Berpotensi } \\
\text { Tumbuh }\end{array}$ & $98.37 \%$ & \multirow{8}{*}{ LDER } & \multirow[t]{2}{*}{2008} & $\begin{array}{l}\text { Tidak Berpotensi } \\
\text { Tumbuh }\end{array}$ & $98.31 \%$ \\
\hline & & Berpotensi Tumbuh & $22.16 \%$ & & & Berpotensi Tumbuh & $22.62 \%$ \\
\hline & \multirow[t]{2}{*}{2009} & $\begin{array}{l}\text { Tidak Berpotensi } \\
\text { Tumbuh }\end{array}$ & $38.36 \%$ & & \multirow[t]{2}{*}{2009} & $\begin{array}{l}\text { Tidak Berpotensi } \\
\text { Tumbuh }\end{array}$ & $17.78 \%$ \\
\hline & & Berpotensi Tumbuh & $29.81 \%$ & & & Berpotensi Tumbuh & $5.46 \%$ \\
\hline & \multirow[t]{2}{*}{2010} & $\begin{array}{l}\text { Tidak Berpotensi } \\
\text { Tumbuh }\end{array}$ & $11.50 \%$ & & \multirow[t]{2}{*}{2010} & $\begin{array}{l}\text { Tidak Berpotensi } \\
\text { Tumbuh }\end{array}$ & $6.05 \%$ \\
\hline & & Berpotensi Tumbuh & $52.30 \%$ & & & Berpotensi Tumbuh & $62.57 \%$ \\
\hline & \multirow[t]{2}{*}{2011} & $\begin{array}{l}\text { Tidak Berpotensi } \\
\text { Tumbuh }\end{array}$ & $98.79 \%$ & & \multirow[t]{2}{*}{2011} & $\begin{array}{l}\text { Tidak Berpotensi } \\
\text { Tumbuh }\end{array}$ & $98.96 \%$ \\
\hline & & Berpotensi Tumbuh & $97.46 \%$ & & & Berpotensi Tumbuh & $97.26 \%$ \\
\hline
\end{tabular}

Sumber : Hasil Olah Data

Tabel 5. Hasil Uji Autokorelasi

\begin{tabular}{|c|c|c|c|c|}
\hline Periode & Dependen & IOS & DW-Hit & Keterangan \\
\hline \multirow{8}{*}{2008} & \multirow{2}{*}{ DTA } & Tidak Berpotensi Tumbuh & 2.215 & Terjadi Autokorelasi Negatif \\
\hline & & Berpotensi Tumbuh & 1.794 & Tidak terjadi autokorelasi \\
\hline & \multirow{2}{*}{ DER } & Tidak Berpotensi Tumbuh & 1.495 & Tidak terjadi autokorelasi \\
\hline & & Berpotensi Tumbuh & 2.454 & Terjadi Autokorelasi Negatif \\
\hline & \multirow{2}{*}{ LDTA } & Tidak Berpotensi Tumbuh & 2.319 & Terjadi Autokorelasi Negatif \\
\hline & & Berpotensi Tumbuh & 2.297 & Terjadi Autokorelasi Negatif \\
\hline & \multirow{2}{*}{ LDER } & Tidak Berpotensi Tumbuh & 1.47 & Tidak terjadi autokorelasi \\
\hline & & Berpotensi Tumbuh & 2.466 & Terjadi Autokorelasi Negatif \\
\hline \multirow{5}{*}{2009} & \multirow{2}{*}{ DTA } & Tidak Berpotensi Tumbuh & 1.94 & Tidak terjadi autokorelasi \\
\hline & & Berpotensi Tumbuh & 1.985 & Tidak terjadi autokorelasi \\
\hline & \multirow{2}{*}{ DER } & Tidak Berpotensi Tumbuh & 2.23 & Terjadi Autokorelasi Negatif \\
\hline & & Berpotensi Tumbuh & 1.765 & Tidak terjadi autokorelasi \\
\hline & LDTA & Tidak Berpotensi Tumbuh & 2.513 & Terjadi Autokorelasi Negatif \\
\hline
\end{tabular}




\begin{tabular}{|c|c|c|c|c|}
\hline Periode & Dependen & IOS & DW-Hit & Keterangan \\
\hline & & Berpotensi Tumbuh & 2.473 & Terjadi Autokorelasi Negatif \\
\hline & I DEP & Tidak Berpotensi Tumbuh & 2.229 & Terjadi Autokorelasi Negatif \\
\hline & LDEK & Berpotensi Tumbuh & 1.853 & Tidak terjadi autokorelasi \\
\hline \multirow{8}{*}{2010} & \multirow{2}{*}{ DTA } & Tidak Berpotensi Tumbuh & 2.06 & Terjadi Autokorelasi Negatif \\
\hline & & Berpotensi Tumbuh & 1.441 & Tidak terjadi autokorelasi \\
\hline & \multirow{2}{*}{ DER } & Tidak Berpotensi Tumbuh & 1.577 & Tidak terjadi autokorelasi \\
\hline & & Berpotensi Tumbuh & 1.834 & Tidak terjadi autokorelasi \\
\hline & \multirow{2}{*}{ LDTA } & Tidak Berpotensi Tumbuh & 2.304 & Terjadi Autokorelasi Negatif \\
\hline & & Berpotensi Tumbuh & 2.271 & Terjadi Autokorelasi Negatif \\
\hline & \multirow{2}{*}{ LDER } & Tidak Berpotensi Tumbuh & 1.654 & Tidak terjadi autokorelasi \\
\hline & & Berpotensi Tumbuh & 1.87 & Tidak terjadi autokorelasi \\
\hline \multirow{8}{*}{2011} & \multirow{2}{*}{ DTA } & Tidak Berpotensi Tumbuh & 1.989 & Tidak terjadi autokorelasi \\
\hline & & Berpotensi Tumbuh & 1.722 & Tidak terjadi autokorelasi \\
\hline & \multirow{2}{*}{ DER } & Tidak Berpotensi Tumbuh & 2.104 & Terjadi Autokorelasi Negatif \\
\hline & & Berpotensi Tumbuh & 2.398 & Terjadi Autokorelasi Negatif \\
\hline & \multirow{2}{*}{ LDTA } & Tidak Berpotensi Tumbuh & 1.857 & Tidak terjadi autokorelasi \\
\hline & & Berpotensi Tumbuh & 2.405 & Terjadi Autokorelasi Negatif \\
\hline & \multirow{2}{*}{ LDER } & Tidak Berpotensi Tumbuh & 2.053 & Terjadi Autokorelasi Negatif \\
\hline & & Berpotensi Tumbuh & 2.412 & Terjadi Autokorelasi Negatif \\
\hline
\end{tabular}

Tabel 6. Hasil Uji Multikolinearitas

Panel A. Model Debt to Total Asset

\begin{tabular}{cccccccccc}
\hline \multirow{2}{*}{ Debt to Total Asset } & \multicolumn{2}{c}{2008} & \multicolumn{2}{c}{$\mathbf{2 0 0 9}$} & $\mathbf{2 0 1 0}$ & \multicolumn{2}{c}{$\mathbf{2 0 1 1}$} \\
\cline { 2 - 9 } & Tolerance & VIF & Tolerance & VIF & Tolerance & VIF & Tolerance & VIF \\
\hline \multirow{5}{*}{ Tidak } & Beta & 0.88 & 1.14 & 0.92 & 1.09 & 0.91 & 1.10 & 0.91 & 1.09 \\
Berpotensi & Size & 0.79 & 1.27 & 0.84 & 1.18 & 0.86 & 1.17 & 0.80 & 1.25 \\
Tumbuh & ROI & 0.48 & 2.09 & 0.55 & 1.83 & 0.66 & 1.51 & 0.89 & 1.12 \\
& EBE & 0.91 & 1.10 & 0.77 & 1.29 & 0.74 & 1.35 & 0.89 & 1.12 \\
& NBTTA & 0.47 & 2.11 & 0.52 & 1.93 & 0.65 & 1.53 & 0.83 & 1.20 \\
& QATA & 0.92 & 1.08 & 0.76 & 1.32 & 0.67 & 1.49 & 0.85 & 1.18 \\
& CACL & 0.75 & 1.34 & 0.88 & 1.14 & 0.78 & 1.29 & 0.88 & 1.13 \\
Berpotensi & 0.78 & 1.28 & 0.81 & 1.23 & 0.82 & 1.22 & 0.89 & 1.12 \\
\hline \multirow{5}{*}{ Tumbuh } & Beta & 0.85 & 1.17 & 0.84 & 1.19 & 0.78 & 1.28 & 0.86 & 1.16 \\
& Size & 0.96 & 1.04 & 0.89 & 1.12 & 0.97 & 1.04 & 0.89 & 1.12 \\
& ROI & 0.74 & 1.35 & 0.80 & 1.25 & 0.64 & 1.56 & 0.79 & 1.27 \\
& EBITTA & 0.79 & 1.27 & 0.74 & 1.35 & 0.90 & 1.11 & 0.93 & 1.08 \\
& NPM & 0.85 & 1.26 & 0.76 & 1.32 & 0.68 & 1.46 & 0.66 & 1.53 \\
& QATA & 0.80 & 1.17 & 0.82 & 1.22 & 0.63 & 1.60 & 0.76 & 1.31 \\
& CACL & 0.97 & 1.04 & 0.76 & 1.32 & 0.80 & 1.26 & 0.78 & 1.28 \\
\hline
\end{tabular}


Panel B. Model Debt to Total Equity

\begin{tabular}{cccccccccc}
\hline \multirow{2}{*}{ Debt to Total Equity } & \multicolumn{2}{c}{$\mathbf{2 0 0 8}$} & \multicolumn{2}{c}{$\mathbf{2 0 0 9}$} & \multicolumn{2}{c}{$\mathbf{2 0 1 0}$} & \multicolumn{2}{c}{$\mathbf{2 0 1 1}$} \\
\cline { 2 - 9 } & Tolerance & VIF & Tolerance & VIF & Tolerance & VIF & Tolerance & VIF \\
\hline \multirow{5}{*}{ Tidak } & Beta & 0.88 & 1.14 & 0.92 & 1.09 & 0.91 & 1.10 & 0.91 & 1.09 \\
Berpotensi & Size & 0.79 & 1.27 & 0.84 & 1.18 & 0.86 & 1.17 & 0.80 & 1.25 \\
Tumbuh & ROI & 0.48 & 2.09 & 0.55 & 1.83 & 0.66 & 1.51 & 0.89 & 1.12 \\
& EBE & 0.91 & 1.10 & 0.77 & 1.29 & 0.74 & 1.35 & 0.89 & 1.12 \\
& NPM & 0.47 & 2.11 & 0.52 & 1.93 & 0.65 & 1.53 & 0.83 & 1.20 \\
& QATA & 0.92 & 1.08 & 0.76 & 1.32 & 0.67 & 1.49 & 0.85 & 1.18 \\
& CACL & 0.78 & 1.34 & 0.88 & 1.14 & 0.78 & 1.29 & 0.88 & 1.13 \\
Berpotensi & 1.28 & 0.81 & 1.23 & 0.82 & 1.22 & 0.89 & 1.12 \\
Tumbuh & ROE & 0.79 & 1.27 & 0.74 & 1.35 & 0.90 & 1.11 & 0.93 & 1.08 \\
& Beta & 0.85 & 1.17 & 0.84 & 1.19 & 0.78 & 1.28 & 0.86 & 1.16 \\
& SBiTe & 0.96 & 1.04 & 0.89 & 1.12 & 0.97 & 1.04 & 0.89 & 1.12 \\
& NPI & 0.79 & 1.26 & 0.76 & 1.32 & 0.68 & 1.46 & 0.66 & 1.53 \\
& QATA & 0.85 & 1.17 & 0.82 & 1.22 & 0.63 & 1.60 & 0.76 & 1.31 \\
& CACL & 0.80 & 1.26 & 0.76 & 1.32 & 0.80 & 1.26 & 0.78 & 1.28 \\
\hline
\end{tabular}

Sumber : Hasil Olah Data

Panel C. Model Long term Debt to Total Asset

\begin{tabular}{|c|c|c|c|c|c|c|c|c|c|}
\hline \multirow{2}{*}{\multicolumn{2}{|c|}{$\begin{array}{l}\text { Long term Debt to } \\
\text { Total Asset } \\
\end{array}$}} & \multicolumn{2}{|l|}{2008} & \multicolumn{2}{|l|}{2009} & \multicolumn{2}{|l|}{2010} & \multicolumn{2}{|l|}{2011} \\
\hline & & Tolerance & VIF & Tolerance & VIF & Tolerance & VIF & Tolerance & VIF \\
\hline \multirow{8}{*}{$\begin{array}{c}\text { Tidak } \\
\text { Berpotensi } \\
\text { Tumbuh }\end{array}$} & Beta & 0.88 & 1.14 & 0.92 & 1.09 & 0.91 & 1.10 & 0.91 & 1.09 \\
\hline & Size & 0.79 & 1.27 & 0.84 & 1.18 & 0.86 & 1.17 & 0.80 & 1.25 \\
\hline & ROI & 0.48 & 2.09 & 0.55 & 1.83 & 0.66 & 1.51 & 0.89 & 1.12 \\
\hline & ROE & 0.91 & 1.10 & 0.77 & 1.29 & 0.74 & 1.35 & 0.89 & 1.12 \\
\hline & EBITTA & 0.47 & 2.11 & 0.52 & 1.93 & 0.65 & 1.53 & 0.83 & 1.20 \\
\hline & NPM & 0.92 & 1.08 & 0.76 & 1.32 & 0.67 & 1.49 & 0.85 & 1.18 \\
\hline & QATA & 0.75 & 1.34 & 0.88 & 1.14 & 0.78 & 1.29 & 0.88 & 1.13 \\
\hline & CACL & 0.78 & 1.28 & 0.81 & 1.23 & 0.82 & 1.22 & 0.89 & 1.12 \\
\hline \multirow{8}{*}{$\begin{array}{l}\text { Berpotensi } \\
\text { Tumbuh }\end{array}$} & Beta & 0.85 & 1.17 & 0.84 & 1.19 & 0.78 & 1.28 & 0.86 & 1.16 \\
\hline & Size & 0.96 & 1.04 & 0.89 & 1.12 & 0.97 & 1.04 & 0.89 & 1.12 \\
\hline & ROI & 0.74 & 1.35 & 0.80 & 1.25 & 0.64 & 1.56 & 0.79 & 1.27 \\
\hline & $\mathrm{ROE}$ & 0.79 & 1.27 & 0.74 & 1.35 & 0.90 & 1.11 & 0.93 & 1.08 \\
\hline & EBITTA & 0.79 & 1.26 & 0.76 & 1.32 & 0.68 & 1.46 & 0.66 & 1.53 \\
\hline & NPM & 0.85 & 1.17 & 0.82 & 1.22 & 0.63 & 1.60 & 0.76 & 1.31 \\
\hline & QATA & 0.80 & 1.26 & 0.76 & 1.32 & 0.80 & 1.26 & 0.78 & 1.28 \\
\hline & CACL & 0.97 & 1.04 & 0.99 & 1.01 & 0.82 & 1.21 & 0.74 & 1.35 \\
\hline
\end{tabular}

Panel D. Model Long term Debt to Total Equity

\begin{tabular}{cccccccccc}
\hline \multirow{2}{*}{\begin{tabular}{c} 
Long term Debt to \\
\multicolumn{2}{c}{ Total Equity }
\end{tabular}} & \multicolumn{2}{c}{$\mathbf{2 0 0 8}$} & \multicolumn{2}{c}{$\mathbf{2 0 0 9}$} & \multicolumn{2}{c}{$\mathbf{2 0 1 0}$} & $\mathbf{2 0 1 1}$ \\
\cline { 2 - 9 } & Tolerance & VIF & Tolerance & VIF & Tolerance & VIF & Tolerance & VIF \\
\hline \multirow{2}{*}{$\begin{array}{c}\text { Tidak } \\
\text { Beta }\end{array}$} & Size & 0.88 & 1.14 & 0.92 & 1.09 & 0.91 & 1.10 & 0.91 & 1.09 \\
Berpotensi & ROI & 0.48 & 1.27 & 0.84 & 1.18 & 0.86 & 1.17 & 0.80 & 1.25 \\
Tumbuh & ROE & 0.91 & 1.10 & 0.55 & 1.83 & 0.66 & 1.51 & 0.89 & 1.12 \\
& EBITTA & 0.47 & 2.11 & 0.52 & 1.93 & 0.65 & 1.53 & 0.83 & 1.20 \\
& NPM & 0.92 & 1.08 & 0.76 & 1.32 & 0.67 & 1.49 & 0.85 & 1.18
\end{tabular}




\begin{tabular}{cccccccccc}
\hline Long term Debt to & \multicolumn{2}{c}{$\mathbf{2 0 0 8}$} & \multicolumn{2}{c}{$\mathbf{2 0 0 9}$} & \multicolumn{2}{c}{$\mathbf{2 0 1 0}$} & \multicolumn{2}{c}{$\mathbf{2 0 1 1}$} \\
\cline { 2 - 9 } Total Equity & Tolerance & VIF & Tolerance & VIF & Tolerance & VIF & Tolerance & VIF \\
\cline { 2 - 9 } & 0.75 & 1.34 & 0.88 & 1.14 & 0.78 & 1.29 & 0.88 & 1.13 \\
QATA & 0.78 & 1.28 & 0.81 & 1.23 & 0.82 & 1.22 & 0.89 & 1.12 \\
\hline CACL & Beta & 0.85 & 1.17 & 0.84 & 1.19 & 0.78 & 1.28 & 0.86 & 1.16 \\
& Size & 0.96 & 1.04 & 0.89 & 1.12 & 0.97 & 1.04 & 0.89 & 1.12 \\
Berpotensi & ROI & 0.74 & 1.35 & 0.80 & 1.25 & 0.64 & 1.56 & 0.79 & 1.27 \\
Tumbuh & ROE & 0.79 & 1.27 & 0.74 & 1.35 & 0.90 & 1.11 & 0.93 & 1.08 \\
& EBITTA & 0.79 & 1.26 & 0.76 & 1.32 & 0.68 & 1.46 & 0.66 & 1.53 \\
& NPM & 0.85 & 1.17 & 0.82 & 1.22 & 0.63 & 1.60 & 0.76 & 1.31 \\
& QATA & 0.80 & 1.26 & 0.76 & 1.32 & 0.80 & 1.26 & 0.78 & 1.28 \\
& CACL & 0.97 & 1.04 & 0.99 & 1.01 & 0.82 & 1.21 & 0.74 & 1.35 \\
\hline
\end{tabular}

Sumber : Hasil Olah Data 